\title{
Status Report on Irradiation Capsules Designed to Evaluate FeCrAl-UO Interactions
}

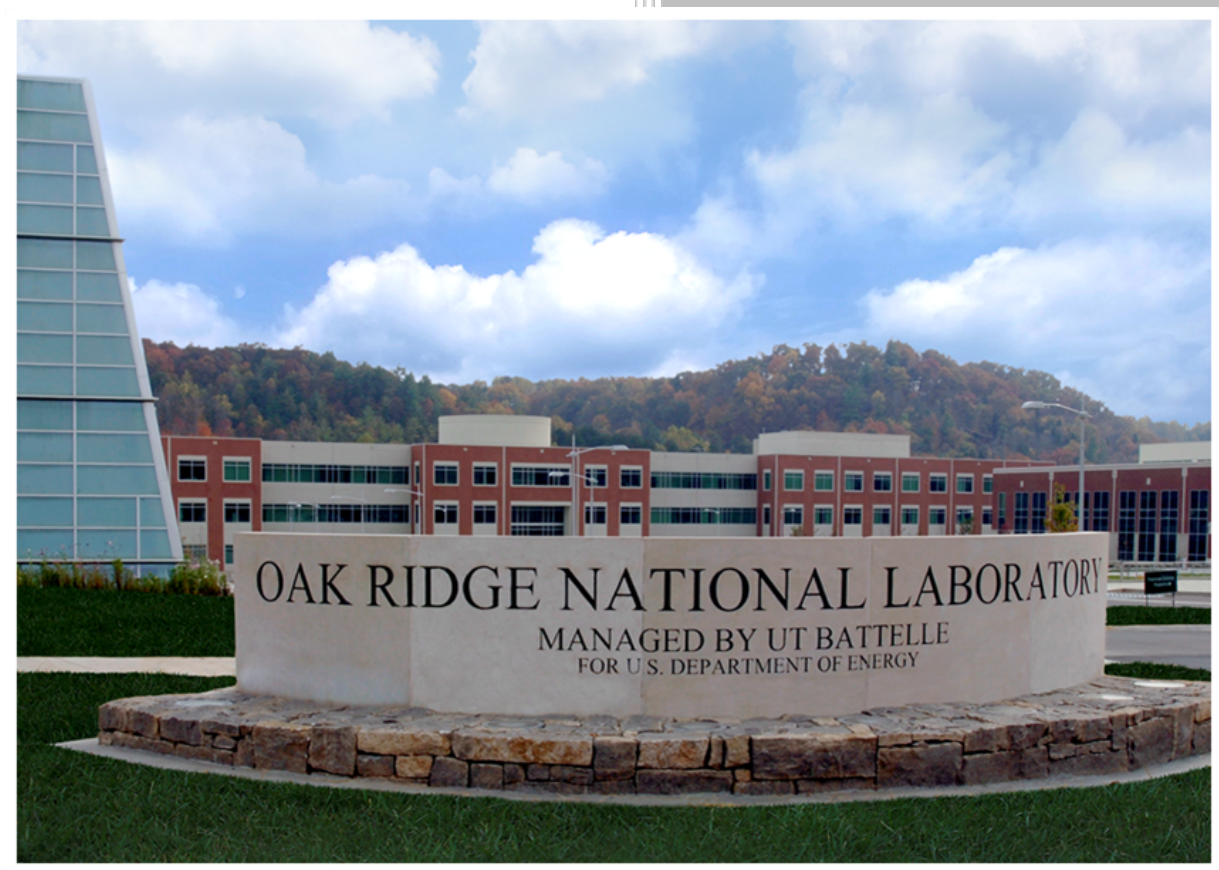

Approved for public release. Distribution is unlimited.

Kevin G. Field

Richard H. Howard

June 24, 2016 


\section{DOCUMENT AVAILABILITY}

Reports produced after January 1, 1996, are generally available free via US Department of Energy (DOE) SciTech Connect.

Website http://www.osti.gov/scitech/

Reports produced before January 1, 1996, may be purchased by members of the public from the following source:

National Technical Information Service

5285 Port Royal Road

Springfield, VA 22161

Telephone 703-605-6000 (1-800-553-6847)

TDD 703-487-4639

Fax 703-605-6900

E-mail info@ntis.gov

Website http://www.ntis.gov/help/ordermethods.aspx

Reports are available to DOE employees, DOE contractors, Energy Technology Data Exchange representatives, and International Nuclear Information System representatives from the following source:

Office of Scientific and Technical Information

PO Box 62

Oak Ridge, TN 37831

Telephone 865-576-8401

Fax 865-576-5728

E-mail reports@osti.gov

Website http://www.osti.gov/contact.html

This report was prepared as an account of work sponsored by an agency of the United States Government. Neither the United States Government nor any agency thereof, nor any of their employees, makes any warranty, express or implied, or assumes any legal liability or responsibility for the accuracy, completeness, or usefulness of any information, apparatus, product, or process disclosed, or represents that its use would not infringe privately owned rights. Reference herein to any specific commercial product, process, or service by trade name, trademark, manufacturer, or otherwise, does not necessarily constitute or imply its endorsement, recommendation, or favoring by the United States Government or any agency thereof. The views and opinions of authors expressed herein do not necessarily state or reflect those of the United States Government or any agency thereof. 
Fuel Cycle Research and Development (FCRD)

\section{Status Report on Irradiation Capsules Designed to Evaluate FeCrAl-UO ${ }_{2}$ Interactions}

Kevin G. Field

Richard H. Howard

Date Published: June 24, 2016

Prepared by

OAK RIDGE NATIONAL LABORATORY

Oak Ridge, TN 37831-6283

managed by

UT-BATTELLE, LLC

for the

US DEPARTMENT OF ENERGY

under contract DE-AC05-00OR22725 



\section{CONTENTS}

Page

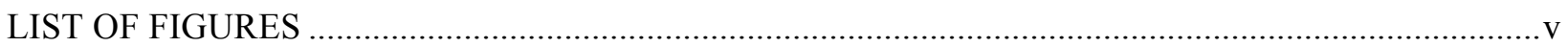

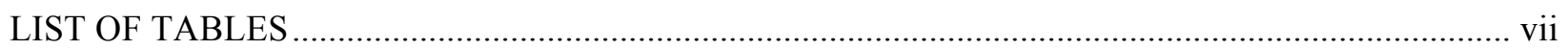

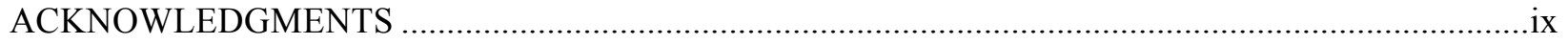

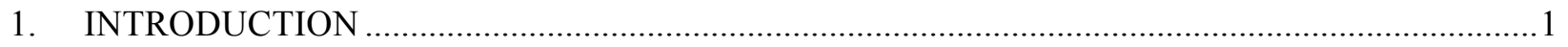

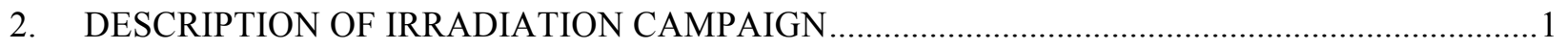

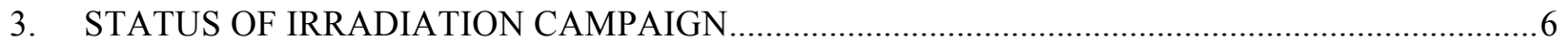

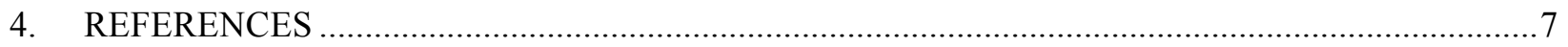





\section{LIST OF FIGURES}

Figure 1. Schematic of ORNL FCCI-ATF rodlet. Image courtesy of Nate Oldham (INL). ......................2

Figure 2. a) "H-cup" piece parts and engraved sample coins, b) SS304L stainless steel capsule

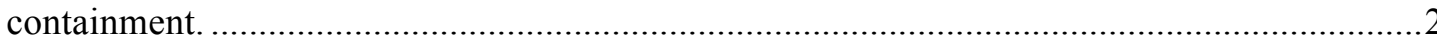

Figure 3. Image of finished $\mathrm{UO}_{2}$ fuel slices after final processing ..................................................... 



\section{LIST OF TABLES}

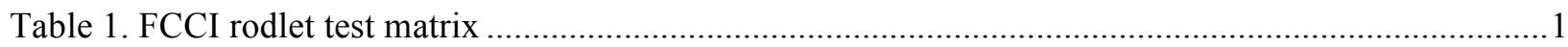

Table 2. Candidate FeCrAl cladding coin compositions in weight percent. ...........................................

Table 3: Specimen ID marking for specimens for irradiation testing ......................................................

Table 4: Per capsule loading list and expected node temperatures during irradiation.................................5

Table 5: Notional cycle information for ATR out to FY20 ................................................................. 



\section{ACKNOWLEDGMENTS}

Research was sponsored by DOE Office of Nuclear Energy, Advanced Fuel Campaign of the Fuel Cycle R\&D program. The authors would like to thank the Idaho National Laboratory's Fuel Development Department and Nuclear Fuel and Materials Department for their on-going support of this research effort. 



\section{INTRODUCTION}

This status report provides the background and current status of a series of irradiation capsules that were designed and are being built to test the interactions between candidate $\mathrm{FeCrAl}$ cladding for enhanced accident tolerant applications and prototypical enriched commercial $\mathrm{UO}_{2}$ fuel in a neutron radiation environment. These capsules will test the degree, if any, of fuel cladding chemical interactions (FCCI) between $\mathrm{FeCrAl}$ and $\mathrm{UO}_{2}$. The capsules are to be irradiated in the Advanced Test Reactor (ATR) at Idaho National Laboratory to burn-ups of 10,30 , and $50 \mathrm{GWd} / \mathrm{MT}$ with a nominal target temperature at the interfaces between the pellets and clad of $350^{\circ} \mathrm{C}$.

\section{DESCRIPTION OF IRRADIATION CAMPAIGN}

$\mathrm{FeCrAl}$ alloys are proving to be an attractive material class for enhanced accident tolerance applications due to their excellent environmental compatibility, including high temperature steam oxidation [1-3], and predictable radiation tolerance $[4,5]$. Given this, a matter of concern is the possibility for fuel-cladding chemical interactions (FCCI) between $\mathrm{FeCrAl}$ and $\mathrm{UO}_{2}$ in a typical clad-fuel fuel-pin configuration. FCCI has been shown to weaken cladding in other clad-fuel systems during operation leading to pre-mature failure of a fuel-rod at lower stresses than expected by simple uniaxial tensile tests. In order to assess the extent of FCCI between the FeCrAl- $\mathrm{UO}_{2}$ clad-fuel system, a systematic irradiation campaign that uses the Advanced Test Reactor (ATR) housed at Idaho National Laboratory (INL) has been launched.

The irradiation campaign will use a simplified diffusion-couple style miniature test rodlet that promotes constant contact between clad "coins" and fuel "discs" followed by post-irradiation examination (PIE). The constant contact between the fuel and clad will enable the highest degree of FCCI to occur over the course of the irradiation tests and hence represents a worst-case-scenario testing condition. Three different burn-ups have been selected for the test: 10, 30, and $50 \mathrm{GWd} / \mathrm{MT}$. These three burn-ups will cover the initial expected lifespan of a FeCrAl- $\mathrm{UO}_{2}$ fuel rodlet with the $10 \mathrm{GWd} / \mathrm{MT}$ rodlet allowing for rapid assessment of early on-set FCCI. All irradiations will be performed to mimic light water reactor (LWR) conditions, and hence the nominal target temperature at the clad-fuel interface is $350^{\circ} \mathrm{C}$. A summary of the experimental test matrix is provided in Table 1.

Table 1. FCCI rodlet test matrix

\begin{tabular}{|c|c|c|c|c|c|}
\hline & & & \multicolumn{2}{|c|}{ Desired Irradiation Conditions: } & Initial \\
\cline { 4 - 5 } Fuel & $\begin{array}{c}\text { Fuel } \\
\text { Enrichment }\end{array}$ & Cladding & $\begin{array}{c}\text { Nominal target } \\
\text { temperature at } \\
\text { interface }\left({ }^{\circ} \mathrm{C}\right)\end{array}$ & $\begin{array}{c}\text { Burn-up } \\
(\mathrm{GWd} / \mathrm{MT})\end{array}$ & $\begin{array}{c}\text { of } \\
\text { Rodlets }\end{array}$ \\
\hline \hline $\begin{array}{c}\text { Commercial } \\
\mathrm{UO}_{2}\end{array}$ & $4.95 \%$ & FeCrAl candidates & 350 & 10 & 1 \\
\hline $\begin{array}{c}\text { Commercial } \\
\mathrm{UO}\end{array}$ & $4.95 \%$ & FeCrAl candidates & 350 & 30 & 1 \\
\hline $\begin{array}{c}\text { Commercial } \\
\mathrm{UO}_{2}\end{array}$ & $4.95 \%$ & FeCrAl candidates & 350 & 50 & 1 \\
\hline
\end{tabular}


To meet the desired test matrix in Table 1, a rodlet assembly has been designed. The assembly uses machined fuel "discs" that have been enriched to a nominal value 4.95\% U-235. These fuel discs are mated on the top and bottom to candidate FeCrAl cladding "coins" to form the diffusion-couple-like experiment. A retention ring encircles the mated clad-fuel "sandwich" that prevents radial swelling of the fuel and ensures continuous contact of the fuel and clad during the irradiation. This sub-assembly is nicknamed the "H-cup" assembly. Each sub-assembly is repeated vertically within the rodlet enabling multiple candidate claddings to be evaluated in a single experiment. Passive SiC thermometry discs are also included to verify as-built simulated temperatures have been reached during irradiation. The complete rodlet assembly is shown schematically in Figure 1. The rodlet assembly will be placed in its own SS304L capsule preventing any coolant water interactions with the test specimens. As-fabricated parts of the 'H-cup'/sample coins and SS304L capsule are shown in Figure 2.

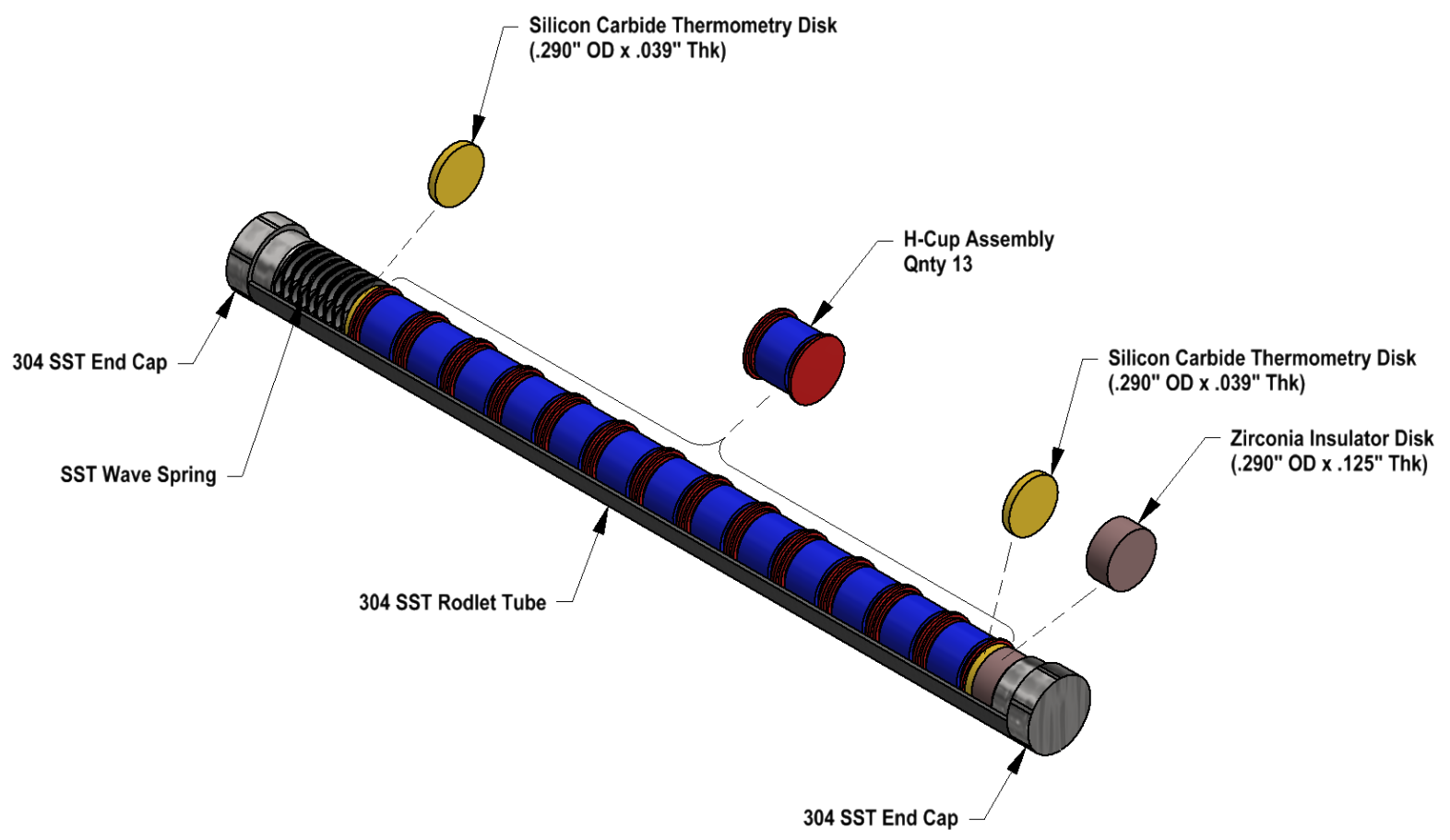

Figure 1. Schematic of ORNL FCCI-ATF rodlet. Image courtesy of Nate Oldham (INL).

a)

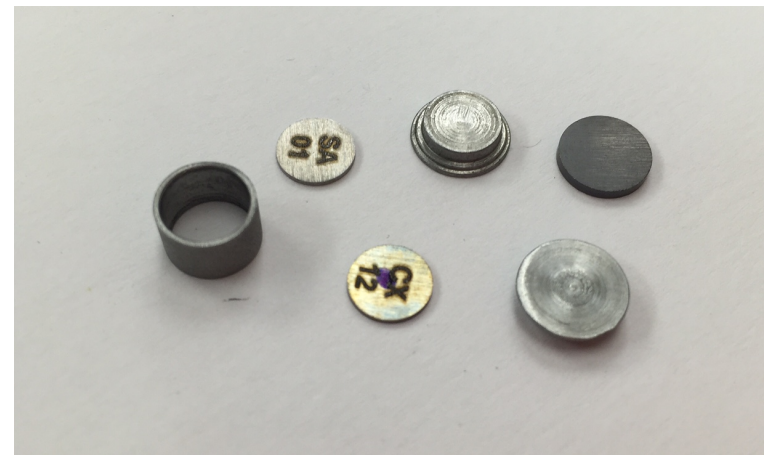

b)

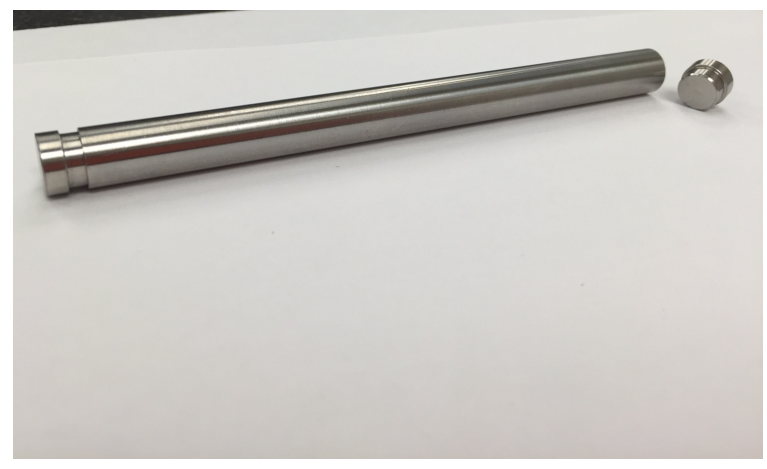

Figure 2. a) "H-cup" piece parts and engraved sample coins, b) SS304L stainless steel capsule containment. 
The fuel discs were manufactured by INL using commercial pellet fuel stock from a single batch. The result is all fuel discs are nominally the same composition. Fuel discs, or slices, were fabricated by performing multiple transverse slices through individual fuel pellets, followed by polishing to provide a mirror like surface on the mating sides. After polishing, the $\mathrm{UO}_{2}$ fuel slices had flatness and parallelism below 0.0001 inches. Following polishing, individual discs were glued together with Macor ${ }^{\mathrm{TM}}$ end slices and then ground down to the final design dimension of 0.249 inches using a centerless grinder. The Macor $^{\mathrm{TM}}$ endcaps were used to eliminate edge chipping during the grinding process. The finished slices were extracted from the glued assemblies by dissolving the glue in acetone. A picture of finished fuel slices is provided in Figure 3.

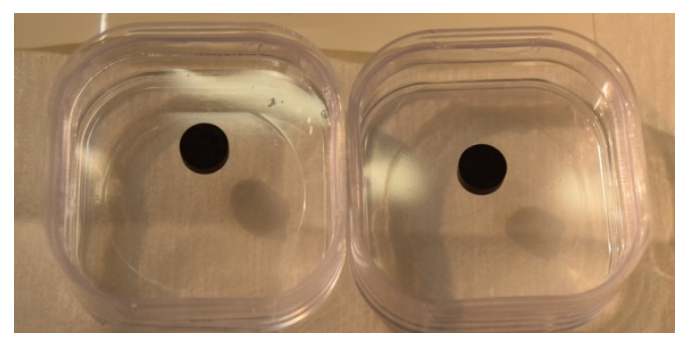

\section{Figure 3. Image of finished $\mathrm{UO}_{2}$ fuel slices after final processing. Image courtesy of Glenn Moore (INL).}

Five base alloys were selected for the FeCrAl cladding coins: C35M3, C37M, B135Y3(SG), B135Y3(LG) and commercial APMT. The C-designated alloys are Generation II FeCrAl alloys designed to have increased high temperature strength compared to the earlier Generation I B-series FeCrAl alloys. Two different versions of B135Y3 will be studied. Both will have identical composition but the thermomechanical processing varies between the two versions such that one has larger grain sizes (LG) compared to the base heat, which has comparably small grains (SG). Varying the initial grain size prior to irradiation will enable evaluation of the role of grain boundaries on any FCCI in the FeCrAl- $\mathrm{UO}_{2}$ cladfuel system. Use of both B-series and C-series alloys will provide an assessment on the role of minor alloying elements (primarily Mo) on the mechanisms for FCCI. APMT, which is a high-Cr commercial FeCrAl alloy, is included in the test matrix to assess its performance in comparison to that of lean-Cr alloys (B and $\mathrm{C}$-series alloys). Table 2 provides the chemical compositions of the alloys to be studied in the test.

A subset of the clad samples to be irradiated in the ATR have been pre-oxidized prior to capsule assembly. Sub-sets of C35M3 alloy samples went through two different pre-oxidation steps, one sub-set being done at $1000^{\circ} \mathrm{C}$ for $2 \mathrm{~h}$ and the other sub-set completed at $800^{\circ} \mathrm{C}$ for $2 \mathrm{~h}$. The logic behind the different oxidation temperatures was to study the effect of different oxide growth and thicknesses on the potential FCCI. It is predicted that the $1000^{\circ} \mathrm{C}$ pre-oxidation in air will form a fully coherent $\alpha-\mathrm{Al}_{2} \mathrm{O}_{3}$ oxide whereas lower temperatures may not. Additionally, the remaining $\mathrm{B}$ and $\mathrm{C}$-series alloys were also pre-oxidized at $1000^{\circ} \mathrm{C}$. The result is that all alloys except the APMT alloy will be irradiated in both the bare metal state (as-machined) and a pre-oxidized state. All manufacturing of clad coins was completed by a single outside vendor to limit differences due to variances in manufacturing practices. Pre-oxidation was carried out at Oak Ridge National Laboratory (ORNL) with pre- and post- oxidation masses recorded for each specimen. After specimen preparation, all samples were cleaned and visually inspected. Samples which did not meet the rigorous quality standards of the program were removed from the sample set for irradiation. Each sample was laser etched to provide a unique sample identity. Laser engraving is used to reduce ridging along the engraving path. Identification marks were placed on the single side of clad coins that were not polished to mirror finish by the manufacturer. The laser marking scheme can be found in Table 3. 
Table 2. Candidate FeCrAl cladding coin compositions in weight percent.

\begin{tabular}{|l|c|c|c|c|}
\hline \multirow{2}{*}{$\begin{array}{c}\text { Composition } \\
\text { wt\% }\end{array}$} & \multicolumn{4}{|c|}{ ID } \\
\cline { 2 - 5 } & C35M3 & C37M & $\begin{array}{c}\text { B135Y3 } \\
\text { (SG/LG) }\end{array}$ & APMT \\
\hline \hline $\mathrm{Fe}$ & 79.43 & 77.49 & 81.72 & 69.01 \\
\hline $\mathrm{Cr}$ & 13.06 & 13.01 & 12.96 & 21.64 \\
\hline $\mathrm{Al}$ & 5.31 & 7.22 & 5.22 & 4.93 \\
\hline $\mathrm{Y}$ & 0.053 & 0.081 & 0.064 & 0.120 \\
\hline $\mathrm{Mo}$ & 2 & 1.99 & $<0.01$ & 2.77 \\
\hline $\mathrm{Si}$ & 0.13 & 0.19 & $<0.01$ & $<0.001$ \\
\hline $\mathrm{Nb}$ & $<0.01$ & $<0.01$ & 0.01 & 0.02 \\
\hline $\mathrm{C}$ & 0.001 & 0.001 & 0.004 & 0.0300 \\
\hline $\mathrm{Zr}$ & $<0.01$ & $<0.01$ & $<0.01$ & 0.1 \\
\hline $\mathrm{Hf}$ & $<0.01$ & $<0.01$ & $<0.01$ & 0.16 \\
\hline $\mathrm{S}$ & $<0.0003$ & $<0.0003$ & 0.0011 & $<0.001$ \\
\hline $\mathrm{O}$ & 0.0012 & 0.0026 & 0.0025 & 0.0494 \\
\hline $\mathrm{N}$ & 0.0003 & 0.0002 & 0.003 & 0.0504 \\
\hline $\mathrm{Ce}$ & $<0.01$ & $<0.01$ & $<0.01$ & $<0.01$ \\
\hline $\mathrm{Co}$ & $<0.01$ & $<0.01$ & $<0.01$ & 0.02 \\
\hline $\mathrm{Cu}$ & $<0.01$ & $<0.01$ & $<0.01$ & 0.04 \\
\hline $\mathrm{La}$ & $<0.01$ & $<0.01$ & $<0.01$ & $<0.01$ \\
\hline $\mathrm{Mn}$ & $<0.01$ & $<0.01$ & $<0.01$ & 0.1 \\
\hline $\mathrm{Ni}$ & $<0.01$ & $<0.01$ & $<0.01$ & 0.12 \\
\hline $\mathrm{P}$ & 0.007 & 0.004 & 0.007 & 0.01 \\
\hline $\mathrm{Ti}$ & $<0.01$ & $<0.01$ & $<0.01$ & 0.02 \\
\hline $\mathrm{V}$ & $<0.01$ & $<0.01$ & $<0.01$ & 0.04 \\
\hline $\mathrm{W}$ & $<0.01$ & $<0.01$ & $<0.01$ & $<0.01$ \\
\hline $\mathrm{B}$ & $<0.0003$ & $<0.0003$ & $<0.001$ & $<0.0003$ \\
\hline
\end{tabular}

Table 3: Specimen ID marking for specimens for irradiation testing.

\begin{tabular}{|c|c|c|c|}
\hline $\begin{array}{c}\text { Spec } \\
\text { ID.** }\end{array}$ & $\begin{array}{c}\text { Specimen } \\
\text { Type }\end{array}$ & $\begin{array}{c}\text { Material } \\
\text { Code }\end{array}$ & Condition \\
\hline \hline CAXX & disc & C35M3 & As-machined \\
\hline 7AXX & disc & C37M & As-machined \\
\hline AAXX & disc & APMT & As-machined \\
\hline LAXX & disc & B135Y3(LG) & As-machined \\
\hline SAXX & disc & B135Y3(SG) & As-machined \\
\hline
\end{tabular}

\begin{tabular}{|c|c|c|c|}
\hline $\begin{array}{c}\text { Spec } \\
\text { ID.** }\end{array}$ & $\begin{array}{c}\text { Specimen } \\
\text { Type }\end{array}$ & $\begin{array}{c}\text { Material } \\
\text { Code }\end{array}$ & Condition \\
\hline \hline CTXX & disc & $\mathrm{C} 35 \mathrm{M} 3$ & $\begin{array}{c}\text { Pre-oxidized, } \\
1000^{\circ} \mathrm{C} / 2 \mathrm{~h}\end{array}$ \\
\hline CXXX & $\operatorname{disc}$ & $\mathrm{C} 35 \mathrm{M} 3$ & $\begin{array}{c}\text { Pre-oxidized, } \\
800^{\circ} \mathrm{C} / 2 \mathrm{~h}\end{array}$ \\
\hline LTXX & $\operatorname{disc}$ & $\mathrm{B} 135 \mathrm{Y} 3(\mathrm{LG})$ & $\begin{array}{c}\text { Pre-oxidized, } \\
1000^{\circ} \mathrm{C} / 2 \mathrm{~h}\end{array}$ \\
\hline STXX & $\operatorname{disc}$ & $\mathrm{B} 135 \mathrm{Y} 3(\mathrm{SG})$ & $\begin{array}{c}\text { Pre-oxidized, } \\
1000^{\circ} \mathrm{C} / 2 \mathrm{~h}\end{array}$ \\
\hline $7 \mathrm{TXX}$ & $\operatorname{disc}$ & $\mathrm{C} 37 \mathrm{M}$ & $\begin{array}{c}\text { Pre-oxidized, } \\
1000^{\circ} \mathrm{C} / 2 \mathrm{~h}\end{array}$ \\
\hline
\end{tabular}


Capsules are planned for insertion into the ATR in the northeast lobe of the ATR in the I-21 irradiation position. It is estimated in this position the average linear heat generation rate (LHGR) will be $142 \mathrm{~W} / \mathrm{cm}$ corresponding to power density numbers similar to those of a typical $\mathrm{LWR} \mathrm{UO}_{2}$ fuel pellet. Based on the LHGR, it is anticipated that the irradiation will take 980 effective full power days (EFPD) to reach the final set-point of $50 \mathrm{GWd} / \mathrm{mTU}$. Due to variations in the axial flux profile in the ATR, an axial thermal gradient is expected within each test capsule. To compensate for the axial gradient, two radial gaps (.001 inch and .002 inch) between the SS304L housing and H-cup will be used. Furthermore, due to the heat removal path of the specimens, some radial temperature profile is expected across the clad-fuel interfaces. The predicted design temperatures at the radial center (central node) of the coin specimens varies in the axial direction between $304^{\circ} \mathrm{C}$ and $381{ }^{\circ} \mathrm{C}$. The temperature at the outer surface (outer node) of the coin specimens (where the assembly contacts the retention ring) is expected to vary in the axial direction between 295 and $362^{\circ} \mathrm{C}$. Based on the thermal models, Table 4 provides the per capsule temperature profiles and final loading list prior to irradiation. Each rodlet-capsule configuration will have a unique identifier associated with it. These identifiers are ATF-73, ATF-74, and ATF-75 for the $10 \mathrm{GWd} / \mathrm{mTU}$, $30 \mathrm{GWd} / \mathrm{mTU}$, and $50 \mathrm{GWd} / \mathrm{mTU}$ rodlets, respectively.

Table 4: Per capsule loading list and expected node temperatures during irradiation.

\begin{tabular}{|c|c|c|c|c|c|}
\hline $\begin{array}{l}\text { Capsule } \\
\text { Position } \\
\end{array}$ & Gap (in.) & $\begin{array}{c}\text { Central } \\
\text { Node }\left({ }^{\circ} \mathbf{C}\right) \\
\end{array}$ & $\begin{array}{c}\text { Outer } \\
\text { Node }\left({ }^{\circ} \mathrm{C}\right) \\
\end{array}$ & $\begin{array}{c}\text { Material } \\
\text { Code } \\
\end{array}$ & Condition \\
\hline $1 \mathrm{a}$ & 0.001 & 381 & 360 & $\mathrm{C} 35 \mathrm{M} 3$ & As-machined \\
\hline $1 \mathrm{~b}$ & 0.001 & & & $\mathrm{C} 35 \mathrm{M} 3$ & As-machined \\
\hline $2 \mathrm{a}$ & 0.001 & & & $\mathrm{C} 35 \mathrm{M} 3$ & Pre-oxidized, $800^{\circ} \mathrm{C} / 2 \mathrm{~h}$ \\
\hline $2 b$ & 0.001 & & & $\mathrm{C} 35 \mathrm{M} 3$ & Pre-oxidized, $800^{\circ} \mathrm{C} / 2 \mathrm{~h}$ \\
\hline $3 a$ & 0.001 & 379 & 362 & $\mathrm{C} 35 \mathrm{M} 3$ & Pre-oxidized, $1000^{\circ} \mathrm{C} / 2 \mathrm{~h}$ \\
\hline $3 a$ & 0.001 & & & $\mathrm{C} 35 \mathrm{M} 3$ & Pre-oxidized, $1000^{\circ} \mathrm{C} / 2 \mathrm{~h}$ \\
\hline $4 \mathrm{a}$ & 0.001 & & & $\mathrm{C} 37 \mathrm{M}$ & Pre-oxidized, $1000^{\circ} \mathrm{C} / 2 \mathrm{~h}$ \\
\hline $4 \mathrm{~b}$ & 0.001 & & & $\mathrm{C} 37 \mathrm{M}$ & Pre-oxidized, $1000^{\circ} \mathrm{C} / 2 \mathrm{~h}$ \\
\hline $5 \mathrm{a}$ & 0.001 & & & $\mathrm{C} 37 \mathrm{M}$ & As-machined \\
\hline $5 b$ & 0.001 & & & $\mathrm{C} 37 \mathrm{M}$ & As-machined \\
\hline $6 \mathrm{a}$ & 0.001 & & & APMT & As-machined \\
\hline $6 b$ & 0.001 & & & APMT & As-machined \\
\hline $7 \mathrm{a}$ & 0.001 & 376 & 360 & $\mathrm{~B} 135 \mathrm{Y} 2(\mathrm{LG})$ & As-machined \\
\hline $7 \mathrm{~b}$ & 0.001 & & & $\mathrm{~B} 135 \mathrm{Y} 2(\mathrm{LG})$ & As-machined \\
\hline $8 \mathrm{a}$ & 0.002 & & & B135Y2(SG) & As-machined \\
\hline $8 \mathrm{~b}$ & 0.002 & & & $\mathrm{~B} 135 \mathrm{Y} 2(\mathrm{SG})$ & As-machined \\
\hline $9 \mathrm{a}$ & 0.002 & & & $\mathrm{~B} 135 \mathrm{Y} 2(\mathrm{LG})$ & Pre-oxidized, $1000^{\circ} \mathrm{C} / 2 \mathrm{~h}$ \\
\hline $9 \mathrm{~b}$ & 0.002 & & & B135Y2(LG) & Pre-oxidized, $1000^{\circ} \mathrm{C} / 2 \mathrm{~h}$ \\
\hline $10 \mathrm{a}$ & 0.002 & & & $\mathrm{~B} 135 \mathrm{Y} 2(\mathrm{SG})$ & Pre-oxidized, $1000^{\circ} \mathrm{C} / 2 \mathrm{~h}$ \\
\hline $10 \mathrm{~b}$ & 0.002 & & & $\mathrm{~B} 135 \mathrm{Y} 2(\mathrm{SG})$ & Pre-oxidized, $1000^{\circ} \mathrm{C} / 2 \mathrm{~h}$ \\
\hline $11 \mathrm{a}$ & 0.002 & 357 & 341 & $\mathrm{C} 35 \mathrm{M} 3$ & Pre-oxidized, $1000^{\circ} \mathrm{C} / 2 \mathrm{~h}$ \\
\hline $11 \mathrm{~b}$ & 0.002 & & & $\mathrm{C} 35 \mathrm{M} 3$ & Pre-oxidized, $1000^{\circ} \mathrm{C} / 2 \mathrm{~h}$ \\
\hline $12 \mathrm{a}$ & 0.002 & & & $\mathrm{C} 35 \mathrm{M} 3$ & Pre-oxidized, $800^{\circ} \mathrm{C} / 2 \mathrm{~h}$ \\
\hline $12 b$ & 0.002 & & & $\mathrm{C} 35 \mathrm{M} 3$ & Pre-oxidized, $800^{\circ} \mathrm{C} / 2 \mathrm{~h}$ \\
\hline $13 \mathrm{a}$ & 0.002 & & & $\mathrm{C} 35 \mathrm{M} 3$ & As-machined \\
\hline $13 b$ & 0.002 & 304 & 295 & $\mathrm{C} 35 \mathrm{M} 3$ & As-machined \\
\hline
\end{tabular}


Prior to loading the irradiation capsules, each specimen and sub component were dimensionally inspected. Samples will then be loaded into the "H-cup" sub-assemblies and then loaded into the individual SS304L outer housings. Care will be taken to record the location of each sample within the rodlet to enable easier PIE after irradiation. After loading, the capsules will be sealed with a circumferential electron beam weld followed by leak testing to verify the hermeticity of the weld. Capsules will then be back filled with He to provide proper thermal heat transfer within the entire irradiation rig. Final inspection will include hydrostatic testing and full rodlet radiography to confirm the quality of the welds, structural integrity, and the condition of the internal components prior to shipment and insertion into ATR.

\section{STATUS OF IRRADIATION CAMPAIGN}

The finished rodlets are anticipated to be completely fabricated and shipped to INL for ATR insertion no later than August $1^{\text {st }}, 2016$. After receiving the finished rodlets, INL will perform the necessary inspections to verify the operational tolerances and quality of the build. Rodlets will then be matched to proper stainless steel outer capsules to complete the final fabrication of the irradiation test assemblies. During this time, an as-built data package for the test assemblies will be completed. This work will culminate into shipment of the test assemblies to ATR no later than the end of the US fiscal year 2016 (FY16) barring no significant change in cycle lengths/timing of the ATR.

All rodlets (ATF-73, ATF-74, and ATF-75) are anticipated to start irradiation in cycle 160B of the ATR. Cycle 160B is slated for full power operation starting on 10/4/2016 with completion on 12/2/2016 at the time of this report. The northeast lobe power is estimated at $21 \mathrm{MW}$. Capsule ATF-73 will run in ATR midway through FY17. With this schedule, PIE can begin during FY17-FY18 to determine the initial low burn-up effects of FCCI on candidate FeCrAl cladding. All other rodlets will run substantially longer, with ATF-74 running through FY19 and ATF-75 running past the currently published operational schedule for the ATR. A summary of the notional ATR cycle schedule and northeast lobe power is provided in Table 5. 
Table 5: Notional cycle information for ATR out to FY20.

\begin{tabular}{|c|c|c|c|c|c|c|c|}
\hline \multirow[b]{2}{*}{ Cycle } & \multicolumn{2}{|l|}{ Outage } & \multicolumn{2}{|l|}{ Press-Up } & \multicolumn{2}{|l|}{ Full Power } & \multirow{2}{*}{$\begin{array}{c}\text { NE lobe } \\
\text { power } \\
\text { (MW) } \\
\end{array}$} \\
\hline & Start & Finish & Start & Finish & Start & Finish & \\
\hline 158B-1 & $1 / 2 / 16$ & $1 / 30 / 16$ & $1 / 30 / 16$ & $2 / 10 / 16$ & $2 / 10 / 16$ & $4 / 1 / 16$ & $19.0 \pm 1.0$ \\
\hline $160 \mathrm{~A}-1$ & $5 / 13 / 16$ & $6 / 22 / 16$ & $6 / 22 / 16$ & $6 / 29 / 16$ & $9 / 27 / 16$ & $10 / 4 / 16$ & $21.0 \pm 1.0$ \\
\hline 160B-1 & $8 / 26 / 16$ & $9 / 27 / 16$ & $6 / 29 / 16$ & 26-Aug & $10 / 4 / 16$ & $12 / 2 / 16$ & $21.0 \pm 1.0$ \\
\hline $162 \mathrm{~A}-1$ & $1 / 6 / 17$ & Feb-17 & $2 / 22 / 17$ & $2 / 28 / 17$ & $2 / 28 / 17$ & $4 / 28 / 17$ & $23.0 \pm 1.0$ \\
\hline 162B-1 & $4 / 28 / 17$ & $5 / 24 / 17$ & $5 / 24 / 17$ & $5 / 30 / 17$ & $5 / 30 / 17$ & $7 / 28 / 17$ & $14.0 \pm 2.0$ \\
\hline $164 \mathrm{~A}-1$ & $8 / 18 / 17$ & $9 / 25 / 17$ & $9 / 25 / 17$ & $10 / 1 / 17$ & $10 / 1 / 17$ & $11 / 24 / 17$ & $14.0 \pm 2.0$ \\
\hline 164B-1 & $11 / 24 / 17$ & $12 / 21 / 17$ & $12 / 21 / 17$ & $12 / 26 / 17$ & $12 / 26 / 17$ & $2 / 23 / 18$ & $14.0 \pm 2.0$ \\
\hline $166 \mathrm{~A}-1$ & $4 / 9 / 18$ & $5 / 30 / 18$ & $5 / 30 / 18$ & $6 / 4 / 18$ & $6 / 4 / 18$ & $7 / 27 / 18$ & $14.0 \pm 2.0$ \\
\hline 166B-1 & $7 / 27 / 18$ & $9 / 19 / 18$ & $9 / 19 / 18$ & $9 / 24 / 18$ & $9 / 24 / 18$ & $11 / 23 / 18$ & $14.0 \pm 2.0$ \\
\hline $168 \mathrm{~A}-1$ & $12 / 31 / 18$ & $1 / 30 / 19$ & $1 / 30 / 19$ & $2 / 4 / 19$ & $2 / 4 / 19$ & $3 / 29 / 19$ & $16.0 \pm 2.0$ \\
\hline 168B-1 & $3 / 29 / 19$ & $4 / 24 / 19$ & $4 / 24 / 19$ & $4 / 29 / 19$ & $4 / 29 / 19$ & $6 / 28 / 19$ & $16.0 \pm 1.0$ \\
\hline $170 \mathrm{~A}-1$ & $8 / 12 / 19$ & $9 / 11 / 19$ & $9 / 11 / 19$ & $9 / 16 / 19$ & $9 / 16 / 19$ & $11 / 1 / 19$ & $18.0 \pm 2.0$ \\
\hline $171 \mathrm{~A}-1$ & $11 / 1 / 19$ & $11 / 20 / 19$ & $11 / 20 / 19$ & $11 / 25 / 19$ & $11 / 25 / 19$ & $1 / 17 / 20$ & $18.0 \pm 2.0$ \\
\hline $173 \mathrm{~A}-1$ & $3 / 2 / 20$ & $8 / 22 / 20$ & $8 / 22 / 20$ & $8 / 27 / 20$ & $8 / 27 / 20$ & $10 / 19 / 20$ & $18.0 \pm 2.0$ \\
\hline
\end{tabular}

\section{REFERENCES}

[1] B.A. Pint, K.A. Terrani, M.P. Brady, T. Cheng, J.R. Keiser, High temperature oxidation of fuel cladding candidate materials in steam-hydrogen environments, J. Nucl. Mater. 440 (2013) 420 427. doi:10.1016/j.jnucmat.2013.05.047.

[2] K.A. Terrani, S.J. Zinkle, L.L. Snead, Advanced oxidation-resistant iron-based alloys for LWR fuel cladding, J. Nucl. Mater. 448 (2013) 420-435. doi:10.1016/j.jnucmat.2013.06.041.

[3] Y. Yamamoto, B.A. Pint, K.A. Terrani, K.G. Field, L.L. Snead, Development and property evaluation of nuclear grade wrought $\mathrm{FeCrAl}$ fuel cladding for light water reactors, Accept. - J. Nucl. Mater. (2015).

[4] K.G. Field, X. Hu, K.C. Littrell, Y. Yamamoto, L.L. Snead, Radiation tolerance of neutronirradiated model Fe-Cr-Al alloys, J. Nucl. Mater. 465 (2015) 746-755. doi:10.1016/j.jnucmat.2015.06.023.

[5] P.D. Edmondson, S.A. Briggs, Y.Yamamoto, R.H. Howard, K. Sridharan, K.A. Terrani, et al., Irradiation-enhanced $\alpha^{\prime}$ precipitation in model FeCrAl alloys, Scr. Mater. 116 (2016) 112-116. doi:10.1016/j.scriptamat.2016.02.002. 